\title{
STUDI PEMANFAATAN LIMBAH KAYU SENGON SEBAGAI BAHAN BAKU PAPAN SEMEN PARTIKEL
}

\author{
Apolonia Asteria Barreto, Dr. Gina Bachtiar, MT, Dra. Nira Nasution, M.Pd
}

\begin{abstract}
Abstrak
Penelitian ini bertujuan untuk mengetahui apakah papan semen partikel dengan menggunakan limbah kayu sengon memenuhi persyaratan Cement-Bonded Particle Boards International Standard (ISO 8335-1987). Penelitian ini dilakukan di Fakultas Kehutanan Institut Pertanian Bogor pada bulan November - Desember 2010. Dalam penelitian ini menggunakan metode eksperimen, dengan populasi adalah papan semen partikel yang menggunakan limbah kayu sengon. Sedangkan sampel pada penelitian ini adalah papan semen partikel limbah kayu sengon.

Hasil uji liliefors untuk normalitas pada taraf signifikan $a=0,01$. Nilai rata-rata tertinggi untuk keteguhan lentur papan semen partikel pada arah $\mathrm{x}$ yaitu 52,86 $\mathrm{kg} / \mathrm{cm} 2$ dan untuk keteguhan lentur arah y yaitu $50,95 \mathrm{~kg} / \mathrm{cm} 2$.

Kesimpulan dari penelitian ini adalah papan semen partikel yang menggunakan bahan campuran limbah kayu sengon memiliki nilai Keteguhan Lentur, Kerapatan dan Kadar Air dibawah nilai standar ISO 8335-1987. Sedangkan nilai Pengembangan Tebalnya memenuhi standar ISO 8335-1987.
\end{abstract}

\section{PENDAHULUAN}

Kayu memiliki sifat dan karakteristik yang unik, kayu merupakan bahan yang paling banyak digunakan untuk keperluan konstruksi. Kebutuhan kayu yang terus meningkat dan potensi hutan yang terus berkurang menuntut penggunaan kayu secara efisien dan bijaksana, antara lain dengan memanfaatkan limbah berupa serat kayu menjadi produk yang bermanfaat.

Oleh karena itu dilakukan pemanfaatan limbah kayu sebagai bahan campuran dalam pembuatan papan semen, papan semen banyak digunakan di Indonesia khususnya untuk dinding, pintu, lantai plafon, atap dan sebagai pembuatan rumah pra pabrik serta penyekat 
bangunan. Papan semen adalah papan tiruan yang dibuat dari campuran potongan kayu serat atau bahan berlignoselulosa lainnya dengan semen sebagai perekat.

Menurut Paribotro et.al. (1977) dalam Sudjatmiko (2005) papan semen dibagi menjadi beberapa jenis yaitu papan semen wol kayu, papan semen pulp dan papan semen partikel. Papan semen wol kayu dibuat dari wol kayu, semen Portland dan bahan kimia tambahan. Papan semen pulp dibuat dari campuran semen Portland, asbes dan bahan pengisi unorganik dengan perbandingan tertentu. Sedangkan papan semen partikel adalah papan semen yang menggunakan potongan kayu kecil seperti serpih dan serbuk gergaji.

Menurut Kamil (1971) dalam Sudjatmiko (2005) Keuntungan dari pemakain papan semen ini adalah biaya yang sangat relatif murah, mudah dipaku, mudah di potong (digergaji), tahan terhadap jamur dan rayap dan mempunyai daya elastis yang lebih baik pada kondisi beban keseimbangan, tahan terhadap api dan memiliki keteguhan tekan dan keteguhan lentur yang tinggi.

Pada penelitian ini digunakan limbah kayu sengon sebagai bahan baku papan semen partikel, pemanfaatan dari limbah kayu sengon sebagai suatu terobosan guna mendapatkan suatu produk bahan bangunan yang bukan berasal dari hutan dan dengan tujuan untuk melestarikan hasil-hasil hutan yang semakin hari kian menipis, maka pada penelitian ini diusahakan untuk mencari data dengan serangkaian rencana pengujian guna mendapatkan suatu kesimpulan dan hasil penelitian mengenai papan semen partikel limbah kayu sengon.

Selain itu kayu sengon (Pharaseriantes flacataria) banyak dikenal dan cukup disukai oleh masyarakat, karena termasuk tanaman yang dapat tumbuh dengan cepat dan jika ditanam pada tanah yang subur dan iklim yang sesuai, tingginya bisa mencapai 7 meter dalam 1 tahun, 18 meter pada umur 3 tahun, dan 30 meter pada umur $9-10$ tahun. Dalam kondisi optimum, pertumbuhan batangnya mencapai $5-7$ meter pertahun, selain itu jenis kayu ini telah dipilih sebagai salah satu jenis pohon yang ditanam dan mempunyai prospek baik dalam pembangunan $\mathrm{HTI}$, baik untuk bahan baku pulp, kertas maupun untuk kayu pertukangan (google, 2008). Kayu yang digunakan dalam penelitian berumur $3-4$ tahun. 
Pada penelitian ini pembuatan papan semen partikel tersebut digunakan sebagai partisi atau penyekat ruangan, menurut Dirjen IKAH (2001) dalam Haroen et all (2007) lembaran partisi digunakan sebagai komponen pemisah atau penyekat dalam struktur bangunan atau rumah. Lembaran partisi merupakan alternative murah dari papan kayu atau tembok, papan partikel umumnya dibuat dari semen atau gypsum dan diperkuat oleh serat atau perekat. Bahan perekat yang biasanya digunakan misalnya lem kayu. Sifat utama partisi yang diperlukan adalah tebal, kadar air, daya serap air dan kekuatan lentur. Partisi yang ideal dikehendaki ketebalannya serendah mukin tetapi kekuatannya terpenuhi. Kadar air partisi harus serendah mungkin, agar struktur bngunan tidak lembab sehingga terhindar dari gangguan jamur. Daya serap air partisi juga diinginkan serendah mungkin sehingga bias memberikan efek perlindungan yang maksimal. Sementara itu kekuatan lentur dikehendaki setinggi mungkin karena fungsinya sebagai komponen struktur bangunan.

Menurut Bambang S. (2004) dalam Haroen et all (2007) ketebalan lembaran partisi akan mempengaruhi terhadap sifat fisik lembaran. Umumnya semakin tebal kekuatannya makin baik, ketebalan dipengaruhi oleh kepadatan bahan dan proses pengepresan. Rata-rata ketebalan partisi yang beredar dipasaran komersial antara 10-12 mm.

Perbandingan bahan untuk campuran papan semen partikel berdasarkan hasil penelitian terdahulu yang memenuhi standar JIS (Triandana, Indra. 2007) menggunakan campuran 2,5 semen : 1,25 air : 1,0 partikel kayu sengon. Senyawa yang umumnya digunakan pada campuran yaitu $\mathrm{CaCl}_{2}$ dan $\mathrm{Ca}(\mathrm{OH})_{2}$ (Paribotro 1977 dalam Sudjatmiko 2005) dengan konsentrasi optimum $2 \%$ untuk mendapatkan papan semen partikel yang memenuhi standar ISO 8335-19872\%. Ketepatan perbandingan bahan dan pengunaan $\mathrm{CaCl}_{2}$ sebagai katalisator juga akan mempengaruhi perekat yang digunakan. Perekat yang digunakan umumnya menggunakan Portland semen.

Dari uraian diatas maka penelitian ini akan melakukan penelitian yang berkaitan dengan papan semen partikel dengan menggunakan perekat yang umum dan perbandingan yang pernah dilakukan oleh penelitian sebelumnya. 


\section{METODA}

Berdasarkan latar belakang masalah maka, dapat diidentifikasikan beberapa masalah sebagai berikut:

a. Apakah limbah kayu sengon dapat digunakan sebagai bahan alternatif campuran pembuatan papan semen partikel?

b. Apakah dengan menggunakan limbah kayu sengon sebagai bahan alternatif campuran papan semen partikel, dapat menghasilkan Keteguhan Lentur, Kerapatan, Kadar Air dan Pengembangan Tebal papan semen partikel yang sesuai dengan standar ISO 8335-1987?

Dari beberapa masalah yang telah diidentifikasi, maka penelitian ini hanya dibatasi pada:

a. Karakteristik yang dinilai pada papan semen partikel adalah Keteguhan Lentur, Kadar Air, Kerapatan, dan Pengembangan Tebal.

b. Bahan baku pembuatan papan semen partikel adalah limbah kayu segon.

c. Standar yang digunakan pada penelitian yaitu standar Cement-Bonded Particle Boards International Standard (ISO 8335-1987).

d. Perbandingan bahan untuk pembuatan papan semen partikel digunakan perbandingan 2,5 semen : 1,25 air : 1,0 partikel kayu sengon.

e. Katalisator $\mathrm{CaCl}_{2}$ yang digunakan sebanyak $2 \%$

f. Semen yang digunakan dalam pembuatan papan semen partikel adalah Semen Portland Komposit (PCC).

Dengan memperhatikan pembatasan masalah diatas, maka perumusan masalah sebagai berikut : Apakah Keteguhan Lentur, Kerapatan, Kadar Air dan Pengembangan Tebal Papan Semen Partikel limbah kayu sengon memenuhi standar Cement-Bonded Particle Boards International Standard (ISO 8335-1987)?

Dari penelitian ini diharapkan untuk menjajaki kemungkinan pemanfaatan limbah kayu sengon sebagai bahan pembuatan papan semen, mengetahui nilai Keteguhan Lentur, Kerapatan, Kadar Air dan Pengembangan Tebal limbah kayu sengon sebagai bahan baku 
papan semen partikel. dan mengembangkan pengetahuan yang didapat dari hasil penelitian untuk kepentingan bersama.

Tujuan operasional penelitian ini adalah untuk mengetahui Keteguhan Lentur, Kadar Air, Kerapatan, dan Pengembangan Tebal papan semen partikel limbah kayu sengon apakah memenuhi standar Cement-Bonded Particle Boards International Standard (ISO 83351987).

Penelitian dilakuakn di Lab Fakultas kehutanan Institut Pertanian Bogor dan menggunakan dua jenis lab, yaitu Lab Bio Komposit untuk pembuatan, pengujian kerapatan dan kadar air, dan lab Keteknikan Kayu untuk pengujian kuat lentur. Waktu penelitian diadakan antara bulan November 2010 sampai Desember 2010.

Penelitian ini menggunakan dua kelompok benda uji, yaitu kelompok eksperimen benda uji papan semen yang menggunakan campuran limbah kayu sengon dan kelompok keteguhan lentur, kerapatan, kadar air dan pengembangan tebal standar yang diisyaratkan dalam ISO 8335-1987sebagai kelompok pembanding.

Variabel yang digunakan dalam penelitian ini dikelompokkan dalam dua variabel :

a. Variabel bebas, penelitian yang terdiri dari perbandingan limbah kayu sengon.

b. Variabel terikat, yaitu nilai keteguhan lentur, kerapatan, kadar air dan pengembangan tebal papan semen partikel yang sesuai dengan ISO 8335-1987.

\section{Bahan}

Bahan yang digunakan dalam pembuatan papan semen partikel adalah, limbah kayu sengon, PCC (Portland Composite Cement), $\mathrm{CaCl}_{2}$ sebanyak $2 \%$ dan air.

a. Limbah kayu sengon

Limbah kayu sengon yaitu sebagai bahan baku papan semen, limbah dalam bentuk potongan-potongan kayu kecil berupa kayu gubal. Yang kemudian potongan-potongan kayu gubal ini dibentuk menjadi partikel kayu dengan menggunakan mesin penghancur (flaker) ayakan 10 mesh $(2,54 \mathrm{~mm})$, rata-rata umur kayu sengon yang di gunakan yaitu bekisar dari 3-4 tahun. 
b. Semen

Semen sebagai bahan pengikat yang digunakan dalam penelitian ini adalah semen PPC (Portland Composite Cement) yang dapat diperoleh dengan mudah di pasaran.

c. Bahan Tambahan

Bahan tambah terdiri dari katalisator yaitu $\mathrm{CaCl}_{2}$ yang dimaksudkan untuk mempercepat proses pengerasan (pengeringan) dan memperkuat daya rekat semen terpakai.

\section{Alat}

Alat-alat yang digunakan adalah timbangan digital, alat pengukur kadar air, plastik, bak pengaduk, triplek, gelas ukur, plat besi ukuran $30 \times 30 \times 1,2 \mathrm{~cm}$ sebanyak dua buah, satu set mesin kempa dingin, rak oven, satu set alat uji keteguhan lentur dan alat bantu lainnya.

\section{Prosedur Penelitian}

Tahap-tahap pembuatan papan semen partikel dilakukan berdasarkan prosedur yang dikembangkan oleh industri papan partikel yang membproduksi panel-panel untuk bangunan gedung yaitu Durisol. Durisol biasanya disebut dengan Bison-Werke, Springe adalah penyuplai utama industri Papan Semen Partikel.

a. Ukuran benda uji Berdasarkan SNI 03-2105-2006 Papan Partikel.

1) Uji Keteguhan Lentur, ukuran sample $5 \times 20 \mathrm{~cm}$.

2) Uji Kadar Air, ukuran sample $10 \times 10 \mathrm{~cm}$.

3) Uji Kerapatan, ukuran sample $10 \times 10 \mathrm{~cm}$.

4) Uji Pengembangan Tebal, ukuran sample $5 \times 5 \mathrm{~cm}$.

5) Untuk ketebalan dibuat sama, yakni 1,2 cm. 


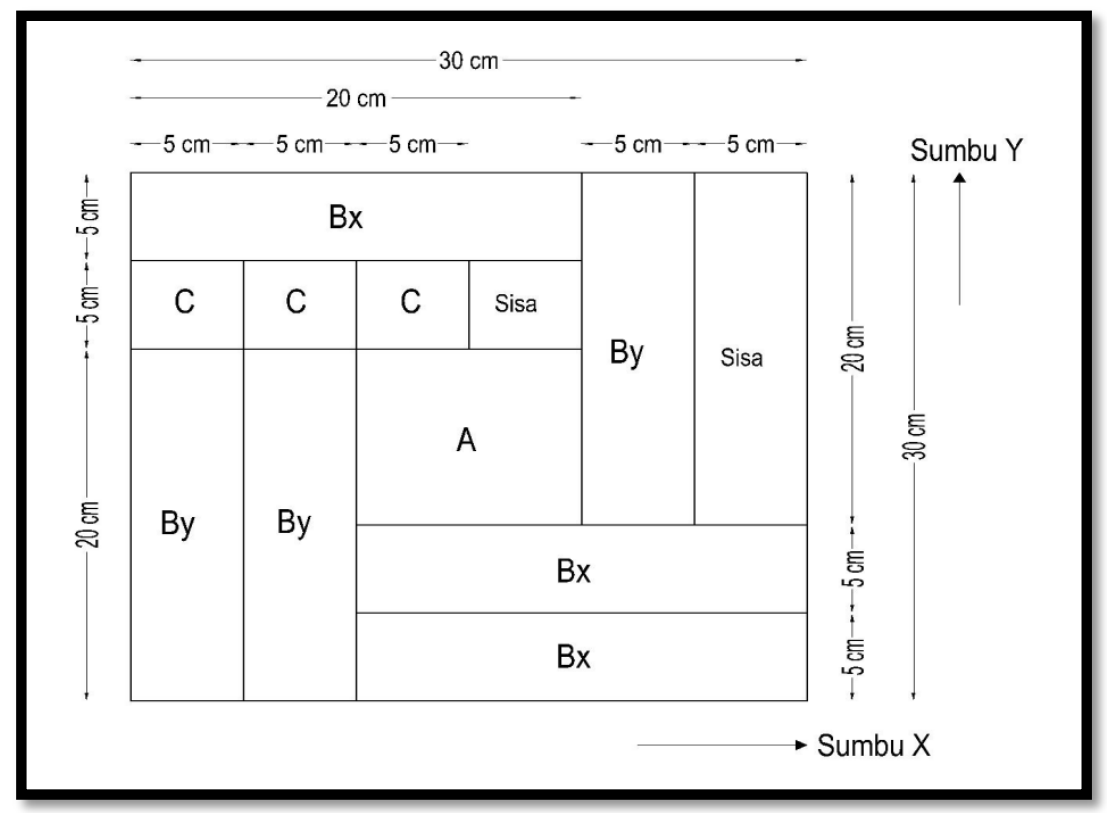

\section{Gambar 1. Pola Pemotongan Contoh Uji}

Cara pengujian untuk papan semen limbah kayu sengon sebagai beriukt.

1) Kerapatan

Pengujian kerapatan papan semen dilakukan pada contoh uji berukuran $10 \times 10 \mathrm{~cm}$ dalam keadaan kering udara, lalu ditimbang beratnya dan diukur rata-rata panjang, tebal dan lebarnya untuk menentukan volumenya. Jumlah contoh uji kerapatan tiap papan adalah satu buah. Kerapatan papan semen dapat dihitung dengan rumus pada prosedur 6.3.2 (ISO 8335-1976):

$$
\mathrm{e}=\frac{m}{V}
$$

Keterangan :

$$
\begin{array}{ll}
\mathrm{e} & =\operatorname{Kerapatan}\left(\mathrm{gr} / \mathrm{cm}^{3}\right) \\
\mathrm{m} & =\operatorname{Berat}(\mathrm{gr}) \\
\mathrm{V} & =\operatorname{Volume} \text { Sampel }\left(\mathrm{cm}^{3}\right)
\end{array}
$$


2) Kadar Air

Contoh uji yang digunakan berukuran $10 \times 10 \mathrm{~cm}$. contoh uji ditimbang, kemudian dioven dengan suhu $103+2{ }^{\circ} \mathrm{C}$ selama 24 jam sampai beratnya konstan. Nilai kadar air dapat dihitung dengan rumus pada prosedur 6.3.3 (ISO 8335-1976):

$$
\mathrm{H}=\frac{m_{0}-m_{1}}{m_{1}}
$$

Keterangan :

$$
\begin{array}{ll}
\mathrm{H} & =\text { Kadar Air }(\%) \\
\mathrm{m}_{0} & =\text { Berat Awal }(\mathrm{gr}) \\
\mathrm{m}_{1} & =\text { Berat Kering }(\mathrm{gr})
\end{array}
$$

3) Pengembangan Tebal

Untuk pengujian ini diperlukan contoh uji berukuran $5 \times 5 \mathrm{~cm}$, lalu diukur dimensinya (pada kondisi kering udara). Dimensi lebar diukur pada kedua sisi kemudian dirata-ratakan, sedangkan tebal diukur pada pusat contoh uji. Selanjutnya contoh uji direndam dalam air dingin selama 24 jam, lalu diukur kembali dimensinya. Nilai pengembangan tebal papan dapat diitung dengan rumus pada prosedur 6.3.4 (ISO 8335-1976):

$$
\mathrm{S}_{24}=\frac{e_{2}-e_{1}}{e_{1}} \times 100
$$

\section{Keterangan :}

$\mathrm{S}_{24} \quad=$ Pengembangan Tebal $(\%)$

$\mathrm{e}_{1} \quad=$ Tebal Awal $(\mathrm{cm})$

$\mathrm{e}_{2} \quad=$ Tebal Setelah Perendaman $(\mathrm{cm})$

4) Keteguhan Lentur (Bending Strength) 
Standar keteguhan lentur yang digunakan dalam penelitian ini adalah sesuai dengan Standard ISO 8335-1987. Pengujian dilakukan dengan menggunakan mesin Universal Test Machine (UTM). Contoh uji berukuran $5 \mathrm{~cm} \times 20 \mathrm{~cm}$ pada kondisi kering udara dibentangkan dengan jarak sangga 15 kali tebal nominal, tapi tidak kurang dari $15 \mathrm{~cm}$, kemudian pembebanan dilakukan pada tengah-tengah jarak sangga, nilai keteguhan lentur dapat dihitung dengan rumus pada prosedur 6.4.3.2 (ISO 8335-1976):

$$
\mathrm{R}_{\mathrm{i}}=\frac{3 P L}{2 b e^{2}}
$$

\section{Keterangan :}

$$
\begin{array}{ll}
\mathrm{R}_{1} & =\text { Bending Strength/Keteguhan Lentur }\left(\mathrm{N} / \mathrm{mm}^{2}\right) \\
\mathrm{P} & =\text { Berat beban sampai patah (Newton) } \\
\mathrm{L} & =\text { Panjang bentang }(\mathrm{mm}) \\
\mathrm{b} & =\text { Lebar contoh uji }(\mathrm{mm}) \\
\mathrm{e} & =\text { Tebal contoh uji }(\mathrm{mm})
\end{array}
$$

$1 \mathrm{~kg} / \mathrm{cm}^{2}=0,09866 \mathrm{~N} / \mathrm{mm}^{2}$

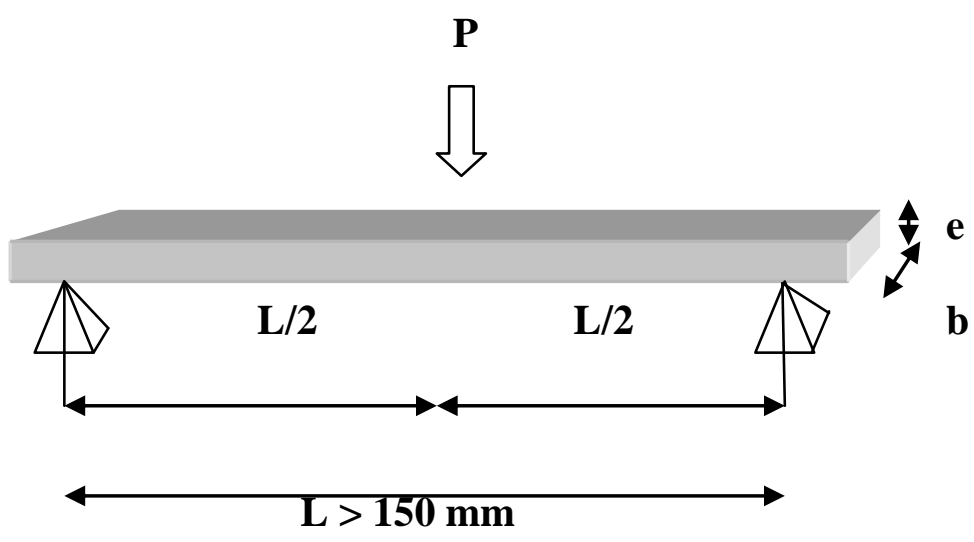

Gambar 2. Pemberian Beban Pada Uji Lentur 


\section{HASIL DAN PEMBAHASAN}

Berdasarkan hasil penelitian dan pengujian yang telah dilakukan menurut ruang lingkup prosedur pada Internasional Standard ISO 8335-1987 mengenai mutu, cara uji dan syarat lulus uji papan semen partikel.

Hasil yang telah disimpulkan dari hipotesis yang telah di uji adalah sebagai berikut:

1) Perbandingan bahan campuran papan semen partikel yang digunakan pada penelitian ini adalah 2,5 semen : 1,25 air : 1,0 partikel kayu sengon yang menghasilkan nilai tertinggi keteguhan lentur arah melebar (x) $52,86 \mathrm{~kg} / \mathrm{cm}^{2}$ dan arah memanjang (y) 50 , $95 \mathrm{~kg} / \mathrm{cm}^{2}$ lebih kecil dari nilai standar ISO8335-1987 $\left(91,22 \mathrm{~kg} / \mathrm{cm}^{2}\right)$.

2) Nilai kerapatan papan semen partikel dari limbah kayu sengon lebih rendah dari nilai standar kerapatan yang ditetapkan ISO 8335-1987 yaitu minimal $1 \mathrm{gram} / \mathrm{cm}^{3}$.

3) Penyerapan air yang didapat $12,28 \%-13,16 \%$, lebih besar dari standar ( $\operatorname{Max}=12 \%$ ). Sehingga tidak cocok digunakan untuk eksterior. 